Bazyli DEGÓRSKI O.S.P.P.E.

(Roma, Angelicum)

\title{
ZARYS ZBAWCZEGO DIALOGU POMIĘDZY BOGIEM A CZLOWIEKIEM W NAUCZANIU OJCÓW KOŚCIOLA OD II DO V WIEKU
}

Najstarsze rozważania Ojców Kościoła na temat zbawczego znaczenia dziejów pojawiły się jako odpowiedź na zagrażający Kościołowi błąd gnozy. Dualizm bowiem filozofii pogańskiej, który podkreślał całkowitą transcendencję Boga względem materialnego świata, oraz jego rozumienie czasu, pojętego jako zdradliwy obraz wieczności, połączył się z eschatologią żydowską, wstrząśniętą zburzeniem Jerozolimy i znalazł ujście w gnozie, która częściowo zazębiła się z chrześcijaństwem pierwszych wieków.

Odbudowanie wielkości politycznej Izraela przez Mesjasza wydaje się zwykłą ułudą. Jedynie więc powrót do stanu czystości pierwotnej może, jak myśleli gnostycy, zapewnić wybawienie. Historia nie przebiega linearnie czy cyklicznie, lecz jest tylko ślepym zaułkiem. Należy więc oprzeć się na religii wewnętrznej, odłączonej od tego świata, który jest tylko narzędziem przewrotnego, złego Boga ciemności, który ten materialny świat uczynił ${ }^{1}$. W oparciu o tę naukę pojawiła się herezja doketyzmu i odrzucenie prawdy o wcieleniu Słowa Bożego.

W niniejszym artykule ukażemy zarys rozumienia historii zbawienia w nauczaniu niektórych najstarszych, bardziej charakterystycznych, Ojców Kościoła, którzy działali na przestrzeni od II do V wieku, a w szczególności: św. Ignacego Antiocheńskiego, św. Justyna, św. Ireneusza z Lyonu, Tertuliana, św. Ambrożego, św. Hieronima i św. Augustyna z Hippony.

1. Św. Ignacy Antiocheński. Jest on jednym z pierwszych Ojców Kościoła, który zdecydowanie przeciwstawia się błędowi doketów i mocno podkreśla prawdę przyjęcia przez Słowo Boże prawdziwego ciała ludzkiego, w którym wiodło ono ziemskie życie, przecierpiało męki i zmartwychwstało: wszystkie te wydarzenia miały dla nas wartość zbawczą. Człowiek więc nie preegzystuje wzlędem czasu, jak nauczali gnostycy, lecz jest powołany, aby żyć w tymże czasie, uświęcać się w nim, realizować i osiągnąć zbawienie².

\footnotetext{
${ }^{1}$ Por. G. Jossa, La teologia della storia nel pensiero cristiano del secondo secolo, Napoli 1965, 60-61.

${ }^{2}$ Por. Ignatius Antiochenus, Epistula ad Epheseos 7, 2; Epistula ad Magnesios 11; Epistula ad Trallianos 9, 1-2; 10-11, 1; Epistula ad Philadelphenos 8, 2; Epistula ad Smyrnaeos 1-3; zob. także
} 
Prorocy Starego Terstamentu zapowiadali przyjście Mesjasza, a ich proroctwa znalazły wypełnienie w zbawczych tajemnicach, których dokonało wcielone Słowo Boże. Prorocy oczekiwali i pokładali nadzieję w tej nowej erze, która cechowała się wyjątkową łaską Chrystusa ${ }^{3}$. Era ta została zapoczątkowana wcieleniem, śmiercią i zmartwychwstaniem Pana, który poprzez te zbawcze wydarzenia odkupił człowieka i cały wszechświat oraz dał nam sposobność osobistego skorzystania z tegoż odkupieńczego zbawienia ${ }^{4}$.

2. Św. Justyn. Dla św. Justyna filozofa, osoby wykształconej, która potrafi także cenić prawdziwe wartości kultury świeckiej, teologia historii nabiera nowego znaczenia, które nie wyklucza nawet zadania, jakie w procesie zbawienia odgrywa także władza świecka ${ }^{5}$. Dla niego bowiem bieg różnych wydarzeń dziejowych, jest tylko splotem między działaniem Boga i wolną odpowiedzią na nie człowieka. Walka pomiędzy odwiecznym Słowem Bożym a szatanem cechowała cały okres, który poprzedził wcielenie Zbawiciela. Teraz jednak pełnia władzy znajduje się w mocy chwalebnego Pana, który kieruje czasami obecnymi i ostatecznymi ${ }^{6}$. On to prowadzi ludzkość, pozostawiając jej jednak zdolność i możliwość wyboru pomiędzy dobrem a złem. Może się to dokonać dzięki rozumowi i wolnej woli, które ludzie otrzymali od Boga w darze ${ }^{7}$.

Także struktury świeckie, które nie podlegają już bezpośrednio władzy Szatana, uczestniczą w zbawczym zamyśle Boga. Chrześcijanie natomiast ani nie pragną osiągać świeckich zaszczytów politycznych, ani nie żywią do nich niechęci, jak to widać na podstawie ich dokładnego wypełniania obowiązków obywatelskich i szacunku, jaki okazują władzy świeckiej ${ }^{8}$. Oczekują oni jednak dóbr nadprzyrodzonych. Nie mogą jedynie zgodzić się na bałwochwalstwo i wymóg oddawania cesarzom czci boskiej ${ }^{9}$. Ci, którzy kierują państwem, powinni zapewnić obywatelom ład i pokój ${ }^{10}$, pamiętając o sądzie ostatecznym, ponieważ upadli aniołowie, którzy sprzeniewierzyli się Bogu, nie zaprzestają niszczycielskiego dzieła i próbują ustawicznie burzyć to, co jest dobre także w świeckich strukturach państwa ${ }^{11}$.

Jossa, La teologia della storia, s. 120-121; C. Fauci, Il senso della vita, il destino dell'uomo. La teologia della storia nelle Epistole ed Omelie di Gregorio Magno, Napoli 2000, 15-18; B. Degórski, Zbawczy dialog Boga z ludźmi w pismach św. Gaudentego z Brescji, Rzym 2001, 25-26.

${ }^{3}$ Por. Ignatius Antiochenus, Epistula ad Philadelphenos 5, 2; zob. także Degórski, Zbawczy dialog Boga, s. 26-27.

${ }^{4}$ Por. Ignatius Antiochenus, Epistula ad Trallianos 9, 1-2.

${ }^{5}$ Por. Jossa, La teologia della storia, s. 169-176.

${ }^{6}$ Por. Iustinus, Dialogus cum Tryphone Iudaeo 32, 3.

${ }^{7}$ Por. tenże, Apologia I 28, 3.

${ }^{8}$ Por. tamże I 11, 1-2.

${ }^{9}$ Por. tamże I 17, 2-3.

${ }^{10}$ Por. tamże I 3, 2.

${ }^{11}$ Por. tamże I 68, 2. 
3. Św. Ireneusz z Lyonu. Największym przeciwnikiem heretyckiej gnozy wśród najstarszych Ojców Kościoła był św. Ireneusz - biskup Lyonu w Galii ${ }^{12}$. Przeciwstawiając się błędom gnostyków Walentynian i Marcjonitów, którzy zaprzeczali łączności i ciągłości wydarzeń, św. Ireneusz głosi ciągłość rozwoju historii, która odzwierciedla rozwój natury ludzkiej, w której zauważamy początek, wzrost i wiek dojrzały ${ }^{13}$. Stosunek, jaki zachodzi pomiędzy Starym a Nowym Przymierzem, ukazuje bowiem trwałość wiary w jedynego Boga i ciągłość prawa naturalnego. Zauważa się jednak także nowość życia łaski, która nadeszła wraz z tajemnicą wcielenia Słowa Bożego ${ }^{14}$.

Chrystus, który prawdziwie stał się człowiekiem dla naszego zbawienia, rekapituluje w sobie całość ludzkości, odnawiając jej dzieje poprzez swe zbawcze dzieło odkupienia. Jest nowym Adamem, początkiem odnowionej ludzkości, której przywraca utracone dary łaski i przynosi nową nadzieję radosnego życia z Bogiem ${ }^{15}$.

Przeciwstawiając się determinizmowi heretyckich gnostyków, św. Ireneusz naucza, że odpowiedź człowieka na wezwanie Boga, wynika z jego wolnej woli. Ta wolna wola jednak nie jest jeszcze doskonała, znajduje się in statu fieri, gdy ją porównamy z doskonałą wolą Boga. Istnieje ona jednak rzeczywiście i przyczynia się do tego, że bieg dziejów historii ma swój głęboki sens, a nie jest tylko chaotycznym zbiorem nie mających ze sobą związku wydarzeń $^{16}$. Słabości i błędy poszczególnych istot zostają zrekompensowane przez życie społeczeństw. Państwo namiast stara się o zachowanie sprawiedliwości, stając się narzędziem opatrzności Boga, która jedynie wszystkim kieruje ${ }^{17}$.

4. Tertulian. Znajmując się znaczniem czasu dla chrześcijanina, Tertulian rozważa szczególnie powiązania, jakie zachodzą pomiędzy wiecznością a czasem jako takim. Według niego wieczność - nieskończoność nie ma ani początku, ani końca. Żadna ponadto rzeczywistość materialnego wszechświata nie należy do wieczności i nie jest nieskończona, ponieważ cały wszechświat został stworzony, a więc miał początek ${ }^{18}$. Nawet dusza człowieka nie jest wieczna, aczkolwiek jest nieśmiertelna, ponieważ także i ona ma początek, będąc stworzona przez Boga. Nic więc z rzeczy stworzonych nie jest wieczne. Dopiero po zmartwychwstaniu będą one trwać wiecznie. Zniszczalność przeto trwać będzie aż do czasu zmartwychwstania, potem jednak zostanie pokonana

${ }^{12}$ Odnośnie do rozumienia historii przez św. Ireneusza, por. A. Quacquarelli, La concezione della storia nei Padri prima di s. Agostino. Parte prima, Roma 1955, 27-30; Fauci, Il senso della vita, s. 18-19; Degórski, Zbawczy dialog Boga, s. 27-28.

${ }^{13}$ Por. Irenaeus Lugdunensis, Adversus haereses IV 11.

${ }^{14}$ Por. tamże IV 13 i 16.

${ }^{15}$ Por. tamże III 2.

${ }^{16}$ Por. tamże IV 2.

${ }^{17}$ Por. tamże V 24.

${ }^{18}$ Por. Tertullianus, De anima 24; zob. także Degórski, Zbawczy dialog Boga, s. 28-30. 
przez niezniszczalność, kiedy to śmierć zostanie zniszczona raz na zawsze przez nieśmiertelnośćc ${ }^{19}$. Jedynie więc Bóg jest prawdziwie wieczny ${ }^{20}$.

Dzieje wszechświata obracają się natomiast pomiędzy dwoma punktami odniesienia - Adamem i Chrystusem, którzy wyznaczają dwie zasadnicze chwile historii wszechświata: stworzenie wszechświata i człowieka, oraz wcielenie Słowa Bożego, które zapoczątkowało czasy ostateczne, w których pojawił się Kościół - nowy Izrael, który kierowany przez opatrznościowy plan Boga prowadzi nie tylko wierzących, ale także cały wszechświat, do chwili powtórnego przyjścia Pana i do wiecznego szczęścia ${ }^{21}$.

Cesarstwo rzymskie jawi się jako szczyt postępu socjalnego i kulturalnego całej ludzkości ${ }^{22}$. Wyznawcy Chrystusa modlą się o pomyślność ziemskiego państwa, aczkolwiek władze świeckie niesłusznie ich prześladują. Chrześcijanie modlą się za cesarzy i cesarstwo, ponieważ - dopóty ono trwa - nie spadną na świat klęski zapowiedziane przez Chrystusa w związku z końcem świata ${ }^{23}$.

Cesarstwo rzymskie przyczynia się więc $\mathrm{w}$ pewien sposób do utorowania drogi chrześcijaństwu, które może nieść Dobrą Nowinę wszystkim ludziom i tak przyczyniać się do zbawienia całego wszechświata. Niemniej jednak Tertulian zdaje sobie całkowicie sprawę, że świeckie struktury państwa rzymskiego są także pełne grzechu i przewrotności. Wskazuje więc na przyszłe, wieczne królestwo Boże jako na cel człowieka i wszechświata, gdzie obecne, ziemskie życie osiągnie pełnię i będzie na wieki cieszyć się nieustannym szczęśsiem ${ }^{24}$. Nieodzownym narzędziem do osiągnięcia tegoż wiecznego szczęścia jest asceza, która pozwala wyzwolić się od ducha tego świata, który należy do szatana, aczkolwiek sam świat został stworzony przez Boga jako bardzo dobry i należy do Pana ${ }^{25}$.

Niestety, wdzierający się coraz bardziej nawet w szeregi chrześcijan grzech spowodował, iż radykalny i porywczy Tertulian zaczął uważać doczesny czas za nieprzyjaciela Boga, a nie - jak uważał wcześniej - za okres próby i łaski. Kartagińczyk zaczął przeto oczekiwać okresu działania Pocieszyciela, który naprawi oziębłość chrześcijan ${ }^{26}$.

5. Św. Ambroży. W nauczaniu św. Ambrożego - w czasach, w których chrześcijaństwo stało się już nawet oficjalną religią cesarstwa rzymskiego, Kościół i państwo są ściśle ze sobą związane i postępują zgodnie razem w czasie, aż do ostatecznego szczęścia w przyszłym wieku. Te dwie wielkie insty-

\footnotetext{
${ }^{19}$ Por. Tertullianus, De resurrectione carnis 58.

${ }^{20}$ Por. tenże, Adversus Hermogenem 7.

${ }^{21}$ Por. tenże, De resurrectione carnis 53.

${ }^{22}$ Por. tenże, De anima 30.

${ }^{23}$ Por. tenże, Apologeticum 30 i 32.

${ }^{24}$ Por. tenże, De resurrectione carnis 19.

${ }^{25}$ Por. tenże, De spectaculis 15.

${ }^{26}$ Por. Quacquarelli, La concezione della storia, s. 66-67; Fauci, Il senso della vita, s. 21.
} 
tucje ukazują bowiem, że dzieje wszechświata skierowane są ku temu jedynemu celowi, osiągnięcie którego staje się sensem dla całej, minionej historii wszechświata.

Kościół skupia w sobie i ukazuje wszystkie okresy zbawienia: przeszłość, teraźniejszość i przyszłość. Stopniowo w czasie dokonało się i nadal będzie się dokonywać zjednoczenie wszystkich ludzi i ich przemiana w nowy lud Boga, który żyje i uświęca się w Chrystusowym Kościele ${ }^{27}$, który wyłonił się z Bożego ludu Starego Przymierza, wzniósł się ponad bezduszne, formalistyczne przestrzeganie Prawa Mojżeszowego, przynosząc całemu światu zbawczą łaskę Chrystusa ${ }^{28}$.

Biskup Mediolanu stara się przeto oczyszczać wspólnotę wiernych od wszelkiego grzechu i wad. Trudności pochodzą także z zewnątrz, gdyż rozwojowi Kościoła przeciwstawiają się z różnych względów poganie i żydzi, utrudniając chrześcijaństwu posłannictwo uszczęśliwiania świata ${ }^{29}$. Nawiązuje się więc walka między Kościołem - Mistycznym Ciałem Chrystusa - civitas Dei, a jego nieprzyjaciółmi - civitas diaboli ${ }^{30}$.

W obronie Kościoła staje również zjednoczone z nim cesarstwo, które rozszerza się także dzięki misyjnemu posłannictwu Kościoła ${ }^{31}$. Chrześcijanie opierają się na ziemskim państwie. Jego więc zagłada oznaczać by mogła koniec świata. Struktury bowiem społeczne państwa, jeśli zgadzają się z wymogami Prawa Bożego, nie pochodzą od diabła. Państwo współpracuje w sposób organiczny z Kościołem, jest odbiciem potrzeby solidarnej współpracy między ludźmi, co zostało w nich zaszczepione przez Boga ${ }^{32}$.

Zagrożenie więc cesarstwa ze strony barbarzyńskich Gotów w 378 r. jest więc dla św. Ambrożego znakiem rychłego końca cywilizacji greckorzymskiej ${ }^{33}$. Stan taki potwierdzają ponadto szerzące się herezje ${ }^{34}$, rozpowszechniająca się niesprawiedliwość ${ }^{35}$ i niemoralnośćc ${ }^{36}$. Są to przejawy działania Antychrysta (filius iniquitatis) zwodziciela czasów ostatecznych ${ }^{37}$.

Budzi się jednak nadzieja na lepszą przyszłość, ponieważ pojawiają się dzielni cesarze i dobrzy chrześcijanie - Gracjan i Teodozjusz ${ }^{38}$ - nowy

${ }^{27}$ Por. Ambrosius Mediolanensis, Explanatio Psalmorum XII 36, 7; tenże, Expositio Evangelii secundum Lucam IX 29; zob. także Degórski, Zbawczy dialog Boga, s. 30-33.

${ }^{28}$ Por. tenże, Expositio Evangelii secundum Lucam VI 23.

${ }^{29}$ Por. tamże VIII 13.

${ }^{30}$ Por. tenże, Expositio Psalmi 118, 15.

${ }^{31}$ Por. tenże, Explanatio Psalmorum XII 45, 21.

${ }^{32}$ Por. tenże, Expositio Evangelii secundum Lucam V 73.

${ }^{33}$ Por. tamże X 10.

${ }^{34}$ Por. tamże X 21.

${ }^{35}$ Por. tamże XVIII 18.

${ }^{36}$ Por. tamże X 11.

${ }^{37}$ Por. tamże X 19.

${ }^{38}$ Odnośnie do położenia Kościoła w tych czasach, por. Vescovi e pastori in epoca teodosiana. In 
Dawid i nowy Samson, którzy pragną, aby Chrystusowa Ewangelia ogarnęła cały świat, także narody barbarzyńskie, jeszcze przed nadejściem końca świata, i aby również żydzi uznali w Chrystusie zapowiedzianego w Starym Testamencie Mesjasza ${ }^{39}$. Cała więc ludzkość powinna - zgodnie z tym, co zamierzył Bóg - przyjąć Chrystusa i zjednoczyę się w jego Kościele ${ }^{40}$.

6. Św. Hieronim. Wypracowując naukę na temat dialogu Boga z człowiekiem w czasie, wykorzystał on swoje wielkie zdolności egzegety i filologa biblijnego, łącząc je z doświadczeniem ascetycznego życia mniszego.

W centrum historii znajduje się, według niego, człowiek, którego Bóg obdarzył wielkim darem wolności, dzięki czemu jest on w pełni odpowiedzialny za swoje czyny. Może więc świadomie i wolno wybrać dobro, względnie skierować się ku złu. Ludzie, umieszczeni w czasie, wydają się częstokroć nie zdawać sobie sprawy, iż ich wolne działanie nie zawsze zgadza się z planem Boga; wybierają grzech, lub marnotrawią cenny czas, poświęcając się czczym i bezużytecznym sprawom ${ }^{41}$. Powinni natomiast pamiętać, że są przeznaczeni do wiecznego życia z Bogiem i za tym życiem winni tęsknić i szukać go, gdyż dopiero w wieczności człowiek znajdzie odpoczynek i radość. Cielesne namiętności, którym często ludzie się oddają, są jedynie przypadłościami, które trwają na tej ziemi i to przez bardzo krótki czas. Należy więc za wszelką cenę szukać zjednoczenia z Bogiem, poświęcając się wyrzeczeniom, umartwieniom i wszelakiej ascezie ${ }^{42}$.

Grzech pogrąża człowieka w śmierci, świętość natomiast jednoczy go z Bogiem i zapewnia mu wieczną młodość i radość. Pojawia się wówczas nowy człowiek, który stał się takim dzięki pokucie, umartwieniu i modlitewnemu zjednoczeniu z Panem. Śmierć otwiera przed takim człowiekiem wieczne podwoje niebiańskiej radości. Już więc samo rozpamiętywanie o śmierci przygotowuje go na wieczną radość przebywania z Bogiem. Jest ponadto skutecznym środkiem ascetycznym, który pozwala unikać grzechu i właściwie oceniać przeszłośćc ${ }^{43}$.

Należy przeto uwolnić czas od panowania rzeczy przemijających i błahych, a oddać go temu, do którego należy - wiecznemu Bogu. Świat bowiem jest polem bitwy, na którym ustawicznie rozgrywa się walka pomiędzy złem a dobrem,

occasione del XVI centenario della consacrazione episcopale di S. Agostino (396-1996). XXV Incontro di studiosi dell'antichità cristiana (Roma, 8-11 maggio 1996), SEA 58, Roma 1997, 371-381.

${ }^{39}$ Por. Ambrosius Mediolanensis, Expositio Evangelii secundum Lucam X 14.

${ }^{40}$ Por. tenże, Expositio Psalmi 118, 12.

${ }^{41}$ Por. Hieronymus, Epistula 60, 19.

${ }^{42}$ Por. Quacquarelli, La concezione della storia, s. 167; Fauci, Il senso della vita, s. 25; zob. także Degórski, Zbawczy dialog Boga, s. 34-35.

${ }^{43}$ Por. Hieronymus, Epistula 60, 14. 
zgodnie z posłannictwem Chrystusa, który przyszedł, aby przynieść miecz, a nie pokój (por. Mt 10,34), walka pomiędzy sługami Pana a szatana ${ }^{44}$.

Nauka o dwóch państwach - Boga i szatana - ukazuje się coraz wyraźniej. Hieronim podkreśla więc, iż nie wystarczy tylko należeć do państwa Bożego, czyli do Kościoła, jedynie formalnie i zewnętrznie, lecz trzeba żyć Ewangelią na codzień, należąc już na tej ziemi do niebiańskiego Jeruzalem ${ }^{45}$.

Realizm chrześcijański łagodzi u św. Hieronima pokusę pesymizmu spowodowanego nie zawsze właściwym korzystaniem przez człowieka z darów naturalnych i nadprzyrodzonych, które otrzymał od Boga. Hieronim zauważa wyraźnie, że Bóg przeprowadza swój zbawczy plan nawet pomimo niewierności człowieka. Po pierwszym bowiem, materialnym stworzeniu pojawia się nowe stworzenie pełne łaski, która zaczyna się w Nowym Testamenci dzięki wcieleniu Słowa Bożego. Połączenie się Adama z Ewą zostaje teraz przemienione i uświęcone poprzez mistyczne zaślubiny Chrystusa z Kościołem, śmierć zaś, która została odziedziczona po pierwszych rodzicach w raju, została pokonana, a wyznawcy Chrystusa stają się nieśmiertelni ${ }^{46}$.

Ułudzie millenaryzmu św. Hieronim przeciwstawia realizm wiary w koniec świata, który niezawodnie nadejdzie, kiedy Antychryst - usiłując bezskutecznie już po raz ostatni stać się panem dziejów - zostanie pokonany podczas powtórnego przyjścia Chrystusa ${ }^{47}$.

Rozmiłowany w piśmiennictwie klasycznym i żyjący w cesarstwie rzymskim, które już otwarło się na Chrystusa, św. Hieronim widzi w tymże cesarstwie opatrznościowe zadanie do spełnienia. Jednoczy ono bowiem wszystkie ludy ziemi, przygotowując je do stania się w jedynej wierze Mistycznym Ciałem Chrystusa. Koniec więc cesarstwa będzie znakiem rychłego końca świata ${ }^{48}$.

7. Św. Augustyn. Myśl patrystyczna na temat teologicznego rozumienia zbawczego dialogu Boga z człowiekiem w historii, osiągnęła w nauczaniu św. Augustyna swój szczyt. Pod wpływem zajęcia Rzymu przez barbarzyńskie wojska Alaryka w 410 r., Biskup Hippony rozpoczyna pisać największą apologię chrześcijaństwa - De Civitate Dei, która stanowi także głęboką refleksję nad właściwym znaczeniem i pojęciem dziejów wszechświata. Do tej pory, jak mogliśmy zauważyć, Ojcowie zajmowali się głównie ukazywaniem i wyjaśnianiem wagi wcielenia Syna Bożego, określeniem społeczeństwa, które to wcielenie przyjęło, zagadnieniami związanymi z przeszłością, z wzajemnymi powiązaniami między Kościołem a państwem, oraz z ostatecznym losem świata. Św. Augustyn natomiast, posługując się i pogłębiając naukę o „dwóch

\footnotetext{
${ }^{44}$ Por. tamże 22, 4.

${ }^{45}$ Por. tamże 58, 2.

${ }^{46}$ Por. tamże $123,11$.

${ }^{47}$ Por. tamże 22, 38; 54, 7; 124, 9.

${ }^{48}$ Por. tamże 121, 11; 127, 16.
} 
państwach", którą wypracował donatysta Tychoniusz, przeprowadza zwartą i organiczną refleksję na temat istoty i celu dziejów ludzkości ${ }^{49}$.

Sedno jego nauki w tym względzie znajduje się w poszukiwaniu utraconej w raju jedności ze Stwórcą, która stanowi podstawę ładu wewnętrznego w człowieku i w społeczeństwie ${ }^{50}$. Dwie przeciwstawiające się sobie miłości zrodziły dwa państwa. Państwo bowiem niebiańskie opiera się na doskonałym i ustawicznym pragnieniu przebywania z Bogiem, na uznawaniu z jednej strony jego wspaniałości i wielkości, a z drugiej - małości i nędzy człowieka. Państwo natomiast ziemskie posiada jedynie pragnienia przyziemne, buntuje się przeciwko wszystkiemu, co jest boskie i niebiańskie, oraz uważa się za ontologicznie samowystarczalne ${ }^{51}$.

Zjednoczenie z Bogiem Trójjedynym, uczestnictwo w jego doskonałości ${ }^{52}$ powinno być jedynym celem człowieka stworzonego na obraz i podobieństwo Pana, który jednak może prawdziwie zjednoczyć się z tym Bogiem, względnie jemu się przeciwstawić5 ${ }^{3}$. Inaczej mówiąc, państwo Boże polega właśnie na eschatologicznym przylgnięciu ludzi do Boga, na uzyskiwaniu pełni podobieństwa do niego i na doskonaleniu się, jak on jest doskonały. We wcielonym Chrystusie dokonuje się zjednoczenie tego, co zostało rozproszone, a łaska, którą on przyniósł, jest siłą, która łączy rozproszone i upadłe stworzenia, tworząc $z$ nich jedno ciało ${ }^{54}$.

Szatan oddzielił się od Boga z powodu pychy, ukazując wyraźnie, że właśnie brak pokory jest powodem braku jedności z Bogiem i pomiędzy bytami rozumnymi ${ }^{55}$. Państwo bowiem diabła odwraca porządek rzeczy, czyniąc ze stworzonej natury bezwzględną wartość, skazując ją w ten sposób na wieczne niezadowolenie ${ }^{56}$.

Dwa państwa są zasadniczo rzeczywistościami mistycznymi ${ }^{57}$, ponieważ państwo Bońe nie utożsamia się całkowicie z działającym na ziemi Kościołem Chrystusowym, a władza państwowa nie może być zawsze uważana za państwo diabła ${ }^{58}$.

Czas, w którym zakorzenione są owe dwie Civitates, jest kategorią prowizoryczną, znikomą i mało znaczącą, nieuchwytną. Człowiek nie może więc na prawdę w nim znaleźć swego wiecznego celu i szczęścia. Św. Augustyn

${ }^{49}$ Por. G. Lettieri, Il senso della storia in Agostino d'Ippona, Roma 1988, 11-28; Degórski, Zbawczy dialog Boga, s. 36-39.

${ }^{50}$ Por. Augustinus Hipponensis, De civitate Dei XIV 13, 1; XIX 6.

${ }^{51}$ Por. tamże XIV 28.

${ }^{52}$ Por. tamże XIV 25-26.

${ }^{53}$ Por. tamże XIV 1, 3.

${ }^{54}$ Por. tenże, In Joannis Evangelium tractatus 26, 13.

${ }^{55}$ Por. tenże, De civitate Dei XI 13.

${ }^{56}$ Por. tenże, De Trinitate XV 24, 44.

${ }^{57}$ Por. tenże, De civitate Dei XV 1, 1.

${ }^{58}$ Por. tamże XV 2. 
ukazuje bowiem saeculum, jako czas upadłego stworzenia, które podlega grzechowi ${ }^{59}$. Biskup Hippony porównuje dzieje ludzkości do szybko płynącej rzeki, w nurtach której płynie zarówno grzech, który pochodzi od pierwszych rodziców, jak i dobro, którego udziela Stwórca. Grzech pierworodny spowodował bowiem dwie rzeczywistości: złą, która cechuje się grzechem i karą za ten grzech; dobrą, która daje początek dalszemu dobru - rozmnażaniu się i zachowaniu rodzaju ludzkiego ${ }^{60}$.

Wieki jednak, które poprzedziły przyjście Chrystusa, podlegały niszczącemu działaniu diabła, skazując człowieka na życie na wygnaniu poza prawdziwą jego ojczyzną ${ }^{61}$. Wraz z wcieleniem Słowa Bożego natomiast rozpoczęło się novum saeculum - okres łaski i zbawienia, który rozciąga się aż do powtórnego przyjcia Pana na końcu świata ${ }^{62}$.

Filozofowie pogańscy nie zdołali wskazać prawdziwego celu dziejów świata ${ }^{63}$, ponieważ tylko we wszechmogącym i wszystko wiedzącym, jedynym Bogu i dzięki jego Objawieniu, które nam przekazał, czas znajduje wytłumaczenie $^{64}$. Po przyjęciu więc Chrystusa zaślepienie pogańskie nie może mieć już miejsca i nie znajduje żadnego usprawiedliwienia ${ }^{65}$.

Jasnym dowodem na to, że z nadejściem Chrystusa zapanowała nowa era świata, jest fakt, że nawet świecka władza państwowa oddaje cześć Trójjedynemu Bogu. Ta władza, która najbardziej i najdłużej podlegała władzy diabła i jemu służyła, staje się teraz pokorną, odrzuca bałwochwalczy kult i służy Bogu i ludziom, oraz ochrania Kościół, ułatwiając mu dzieło ewangelizacji ${ }^{66}$.

Władza natomiast państwowa doznaje błogosławionej, Bożej pomocy ze strony chrześcijaństwa, które pozostaje ponad wszelką skrukturę polityczną, uważając, by nie stać się w ręku państwa zwykłym instrumentum regni $i^{67}$.

To nowe, dogodne położenie ludzkości należącej do Chrystusa nie może jednak całkowicie przekreślić specyfiki czasu, do której należą boleści i doświadczenia, wzdychanie do lepszego świata ${ }^{68}$, współistnienie dobra ze złem ${ }^{69}$, które Bóg dopuszcza aż do czasu sądu ostatecznego, kiedy to dobro zostanie wiecznie i ostatecznie nagrodzone, a zło - ukarane. Obecnie natomiast nie jesteśmy w stanie przeniknąc tajników sumień ludzkich, chociaż jednak fakt, że

\footnotetext{
${ }^{59}$ Por. tamże XV 1, 1.

${ }^{60}$ Por. tamże XXII 24.

${ }^{61}$ Por. tamże XIII 14.

${ }^{62}$ Por. tamże XVII 5, 2.

${ }^{63}$ Por. tenże, De Trinitate IV 16, 21.

${ }^{64}$ Por. tenże, De civitate Dei XVI 37.

${ }^{65}$ Por. tamże XVI 2, 1; XVII 5, 2.

${ }^{66}$ Por. tamże V 24 i 26.

${ }^{67}$ Por. tamże XIX 17.

${ }^{68}$ Por. tenże, In Joannis Evangelium tractatus 63, 1.

${ }^{69}$ Por. tenże, De civitate Dei I 35.
} 
ktoś znajduje się poza Kościołem z powodu schizmy lub błędnowierstwa jest już znakiem jego potępienia ${ }^{70}$.

Streszczając zatem myśl św. Augustyna, możemy powiedzieć, że na tym świecie człowiek musi stale stawiać czoła niestałościom i trudnościom, jakie niesie skończony czas $^{71}$, różnym podziałom, dualizmom, wzdychając ustawicznie do zjednoczenia się $\mathrm{w}$ wieczności $\mathrm{z}$ Bogiem ${ }^{72}$. Tylko pokorne poddanie się ojcowskiemu działaniu i kierownictwu Boga, zaufanie jego łasce, pośrednictwo Słowa Wcielonego, które wzięło na siebie nasze słabości, otwierają przed człowiekiem bramy wiecznej szczęśliwości ${ }^{73}$.

\section{IL DIALOGO SALVIFICO TRA DIO E L'UOMO NELL'INSEGNAMENTO DEI PADRI DELLA CHIESA DAL II AL V SECOLO. UNO SCHIZZO}

\section{(Riassunto)}

L'articolo presenta uno schizzo della storia della salvezza secondo l'insegnamento di alcuni più caratteristici Padri della Chiesa, dal II al V secolo, e in particolare: sant'Ignazio di Antiochia, san Giustino, sant'Ireneo di Lione, Tertulliano, sant'Ambrogio, san Girolamo e sant'Agostino d'Ippona.

\footnotetext{
${ }^{70}$ Por. tenże, In Joannis Evangelium tractatus 6, 14.

${ }^{71}$ Por. tenże, Confessiones VII 21, 27.

${ }^{72}$ Por. tamże XI 14, 17.

${ }^{73}$ Por. tamże XI 29, 39.
} 